\title{
Legal Aspects Of Deposits As Credits Guarantee To Bank (Study At PT. Bank Danamon, Tbk)
}

\section{Zaini Hafiz Hasibuan}

Sumatera University Faculty Of Law. E-mail: zainihafiz@gmail.com

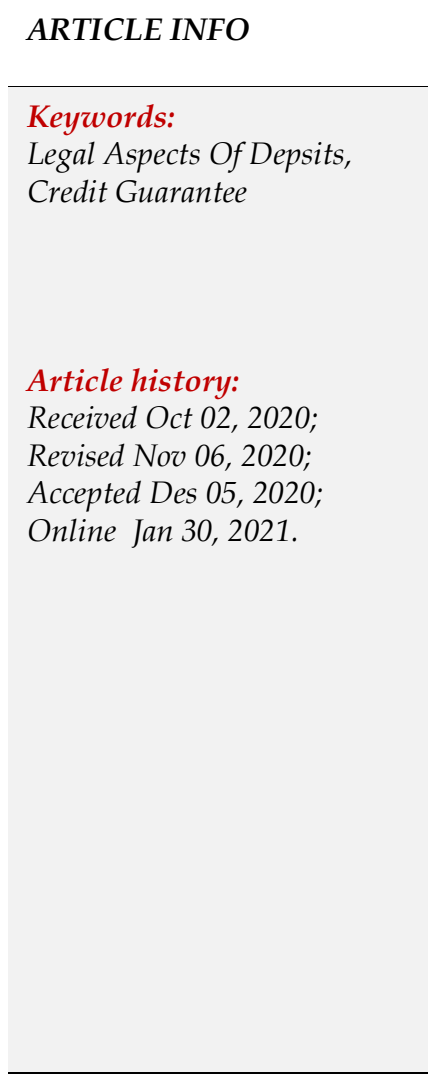

\begin{abstract}
In general, economic activity in Indonesia is related to the general public with funds, meaning that every implementation of development requires funds for the continuity of the development. So that funds are a driving force that has such a big influence for progress in all aspects of the fields in the overall life of the nation and state. Likewise, business actors, both individuals and business entities, in carrying out development or business activities will require large amounts of funds, in the sense that the amount exceeds the funds and capital they have. One of the efforts for capital or funds is through bank credit facilities. So, it is appropriate to be able to understand how the implementation of credit agreements, how the efforts made in disbursing credit. This research uses a normative juridical approach proposed by Soerjono Soekamto, is a research study that emphasizes the science of law and tries to examine the legal rules and norms that apply in the midst of society. From a research result, it is found that First, in general, the implementation of credit agreements with deposit guarantees at first, prospective debtors must apply for credit by filling out the form as provided by the bank and completing all the administration, then the bank the bank performs a credit analysis to assessing the ability and feasibility of the debtor applying for credit. Second, after the application is received by the bank, the bank then makes disbursement efforts by binding it by signing and signed by the debtor (credit applicant) a letter of agreement and other documents that must be filled in for the credit disbursement process.
\end{abstract}

This is an open access article under the CC BY-NC license.

\section{Introduction}

Developments in the world of the national economy provide many phenomenal and alternative impacts in economic activities in Indonesia. This sustainable development is in the context of realizing a just and prosperous society based on Pancasila and the 1945 Constitution. In order to achieve these objectives, the implementation of development must always pay attention to the harmony, harmony and balance of various elements of development, including in the economic and financial fields.

In Indonesia itself development is carried out in all aspects of life, but economic development is a very big driver for progress in other fields in the whole life of the nation and state.

Economic development is closely related to funds, meaning that every carrying out development requires funds for the continuity of the development. Likewise for business actors, whether individuals or business entities, in carrying out development or business 
activities will require funds that are not small, in the sense that the amount exceeds the funds they have.

According to Remy Sjahdeini, funds are the 'blood' for business actors in carrying out their business activities. Like humans who cannot live without blood, business actors too will 'die' without funds. ${ }^{1}$ Funds for the initial business come from the capital (equity) of the company/individual business actor himself, and because it is not sufficient, it is necessary to look for additional funds, among others by obtaining a loan or debt.

In this case, what is meant by the party borrowing funds is the debtor and the party providing the loan is called the creditor, while the money loan facility with repayments in installments or a loan up to a certain amount permitted by the Bank or other entity is called credit.

One of the efforts to obtain capital is through bank credit facilities. In lending activities, there is a basic element in the form of trust, where the Bank as the lender must believe that the credit recipient can return the loan that is owed. Law Number 7 of 1992 concerning Banking as amended by Law Number 10 of 1998 concerning Banking provides guidelines so that banks in carrying out lending are always based on the belief that debtors are able to repay the credits obtained at the agreed time. In other words, the credit given is guaranteed to be returned.

To obtain this assurance, before the bank gives approval for the requested credit, it is necessary to conduct a careful assessment of the character, ability, capital, collateral and business prospects of the debtor. The implementation of lending from creditor banks to debtors is carried out by entering into an agreement. The credit agreement consists of the main agreement, namely the loan agreement between the creditor bank and which is usually followed by an additional agreement in the form of providing guarantees by the debtor to the creditor bank. The binding of collateral is a form of credit security in banking practice.

In practice, even though there are guarantees of a general nature, special guarantees are still needed, both material such as mortgages, creditverbands, pawns, fiduciaries, as well as individual ones such as borgtocht (guaranteed agreements). Today, most banking institutions are very careful in disbursing credit. One of the most basic factors that make it difficult for banks to disburse credit at this time, is none other than the psychological factor of the banking sector itself. The trauma of bad credit and accusations of credit scandals have had a major impact on credit disbursement, in addition to the current view that the real sector has not yet recovered, although liquidity and banking financial ratios are quite possible.

In today's economic development, the needs of the community in obtaining credit facilities are quite large to obtain capital in developing their business. In this case, the bank offers credit with a deposit guarantee. Time Deposit is the name given to a deposit in a bank which is usually attached to the terms of the deposit period. The deposit itself can be in the form of certificates of deposit and bilyet deposits (time deposits).

Entrepreneurs who often have excess cash in practice prefer to keep their money in deposits rather than keep their money in a safe, because in deposits they will earn interest which is also safer.

\section{Method}

In conducting this research, the author uses a sociological juridical approach, namely research that emphasizes the science of law and tries to examine the legal rules that apply in society. The data that has been obtained from the field research will be linked to the literature study. Then the data was analyzed logically and compiled using qualitative methods, namely what was 
stated by the informants in writing and orally researched and studied and then analyzed descriptively qualitatively arranged in systematic sentences.

\section{Analysis And Results}

\subsection{Overview Of Credit Agreements By Bank With Deposite Guarantee}

\section{a. Understanding and Legal Basis About Credit}

The definition of credit itself has various dimensions, starting from the meaning of the word "Credit" which comes from the Greek "Credere" which means "Trust" or in Latin "Creditum" which means belief in the truth.

According to OP Simorangkir, that credit is the provision of achievements (eg money, goods) in return for achievements (counter achievements) that will occur in the future. Today, modern economic life today is a feat of money. Credit functions cooperatively between the lender (creditor) and credit recipient (debtor), they attract profits and bear each other's risks. In short, credit in a broad sense is based on the components of trust, risk, and economic exchange in the future.

Meanwhile, from an economic point of view, credit is defined as the provision of money or bills. According to Article 1 point (11) of Law No. 10 of 1998 concerning Amendments to Law no. 7 of 1992 concerning Banking (Banking Law) credit is the provision of money or equivalent claims, based on an agreement or loan agreement between a bank and another party which requires the borrower to repay his debt after a certain period of time with interest.

b. Implementation Of Credit Agreement With Deposit Guarantee at PT Bank Danamon Indonesia Tbk Medan Branch

In the implementation of binding deposits as credit guarantees, it is carried out by:

1) Binding of deposits is done by making a deed of pledge agreement between the owner of the deposit and the bank. According to the law, a pawn agreement deed can be made legally by notarial or underhand, which is made to support the principal debt agreement which is usually in the form of a debt agreement.

2) To charge a lien, after the deed of the pledge agreement between the deposit owner and the bank, it is followed by the submission of a deposit slip which will be "guaranteed to the pledge holder, in this case the bank. The surrender is a real surrender, it must not only be based on a statement from the pawnbroker, but the object is still in his control. This real surrender coincides with the juridical surrender, so that the surrender is an element of the legality of the pawn.

The owner of the deposit/debtor must authorize the holder of the pledge/the bank to make the withdrawal of the deposit in the event that the owner of the deposit/debtor is in default to make it easier for the creditor to take repayment.

\section{c. Efforts Made by Banks in Loan Disbursement With Deposit Guarantees}

PT Bank Danamon, Tbk Medan Branch as one of the largest and most trusted banks in Indonesia has extended credit to the public in various forms, including; in the form of mortgage rights, transfer of ownership rights to trust/fiduciary, pawn (pand) and belening, transfer of receivables (cessie), pawn pensions/benefits and debt support (borgh tocht).

In addition to the forms mentioned above, the form of lending to the public by PT Bank Danamon Indonesia Tbk Medan branch can be done with Cash Collateral, where one form of cash collateral that can be accepted as credit guarantee at PT Bank Danamon Indonesia Tbk 
Medan branch is Time Deposits. , Certificates of Deposit and other types of deposits issued by the Branch Office of PT Bank Danamon Indonesia Tbk Medan.The relationship begins with the customer's arrival at the Medan branch of PT Bank Danamon's office during business hours to fill in the form of the Borrowing Application Certificate (SKPP) available at PT Bank Danamon's Medan branch.

Based on this, an agreement on a credit agreement can be formulated outside the office of PT Bank Danamon Indonesia Tbk Medan branch between bank employees and customers, for example through non-formal meetings between customers and bank employees, but the implementation of agreements and administrative settlements must still be completed at the PT Bank Danamon office. Indonesia Tbk Medan branch. Thus, it is also not permitted if the credit agreement file is delivered and picked up by a bank employee at the customer's home.

Customers who intend to apply for credit with guaranteed deposits must fill out a Certificate of Borrowing Application (SKPP) which generally contains the customer's application to obtain credit at PT Danamon Tbk Medan branch by stating the name, address, place and date of birth, status, citizenship, proof of documents provided. important, mention the group of companies (if in the form of legal entities), type of business, purpose of using credit facilities, mention the type of currency, amount and term of credit, state whether or not there are financial statements for the last 3 years, types of collateral submitted, to support credit, stating whether or not other guarantees exist, whether the customer has ever been in arrears on past credit or declared bankrupt, whether the customer has taken other credit and mentions if there are references.

For individual customers (prospective debtors), the Certificate of Borrowing Application (SKPP) submitted is required to attach a valid copy of the identity (Kartu Identity Card) which is still valid in the name of the applicant and his wife (if the husband is applying) or husband (if the wife is submitting) the application. credit. Next, attach a Taxpayer Identification Number (NPWP) if the loan amounts to IDR 100,000,000 (one hundred million rupiah).

PT Bank Danamon Indonesia Tbk Medan Branch does not accept if only one of the husband or wife who is still bound by marriage submits the application himself, but always requires the applicant who is bound in marriage to include a Power of Attorney from the spouse if it does not include a copy of the spouse's identity. This is done to protect the possibility in the future from the emergence of demands from the prospective debtor pair.

The power of attorney from the applicant's spouse contains the identity of the giver of the power of attorney and the amount of the deposit to be guaranteed. The power of attorney is enough to be given under the hand by fulfilling the stamp duty. If the applicant (prospective debtor) is a legal entity, then in addition to the general requirements, namely a copy of the operator's identity, it is also required to include business licenses such as Trading Business Permits (SIUP), Company Registration Certificates (TDP) and others.

Deposits that will be used as credit at PT Bank Danamon Indonesia Tbk Medan Branch are generally owned by the applicant (prospective debtor) himself, but PT Bank Danamon Indonesia Tbk Medan branch does not rule out the possibility of providing credit with deposit guarantees that are not owned by the applicant (prospective debtor himself).

If the deposit that will be used as collateral does not belong to the applicant (prospective debtor) himself, then PT Bank Danamon Indonesia Tbk Medan Branch requires that there is a close relationship between the deposit owner and the applicant (prospective debtor), whether by blood or by marriage, not more than three degrees - For example, the owner is the mother while the person applying for the loan is the child - which in this case is required to be accompanied by a power of attorney from the deposit owner to the applicant (prospective 
debtor) to guarantee the deposit belonging to the person concerned at PT Bank Danamon Indonesia Tbk Medan Branch by stating the amount of the deposit and the amount loan.

\section{d. Settlement of Deposits as Credit Collateral If the Debtor Defaults at PT Bank Danamon Indonesia Tbk}

In the implementation of an agreement, basically it does not always run smoothly for the parties in their efforts to fulfill their achievements. Often there is a binding or an act of not fulfilling the contents of the agreement, if a debtor does not fulfill his obligations, according to legal language he commits a "default" which causes him to be sued before a judge. The word default comes from the Dutch language, which means bad.

If a debtor has been warned with his promise and if he still does not perform his achievements, then he is in a state of negligence or neglect.

In essence, the default (negligence or negligence) of a debtor can be in the form of four types, namely:

1) Didn't do what it was supposed to do.

2) It does what it promises, but not as promised.

3) Did what it promised but it was too late.

4) Doing something that according to the agreement is not allowed to do.

Furthermore, what can be sued against a debtor who is negligent of his usual agreement, the creditor can choose between various possibilities, namely:

1) Can request the implementation of the agreement, even though the implementation is too late without paying the penalty or interest determined by the creditor.

2) Can ask for compensation only for losses suffered by the creditor, because the agreement was not implemented or was late, or it was implemented but not as it should be.

3) Can demand the implementation of the agreement accompanied by compensation for losses suffered by the creditor as a result of the delay in the agreement.

4) In the case of an agreement that places reciprocal obligations, the negligence of one party gives the other party the right to request the judge to cancel the agreement, accompanied by a request for compensation.

However, on the other hand, a person or debtor who is accused of being negligent or in breach of contract can make a defense by:

1) Proposing a state of coercion (overmacht or force majeure).

2) Propose that the creditor himself has also been negligent (exetio no adimpleti contractus).

3) Propose that the creditor has waived his right to claim compensation (rechtsverwerking or waiver).

Because default (negligence) has very important consequences, it must be determined beforehand whether the debtor is in default or negligent, and if this is denied by him, it must be proven before a judge. Sometimes it is also not easy to say that someone is negligent or negligent, because often it is also not promised exactly when a party is required to perform the promised performance. In buying and selling goods, for example, it is not stipulated when the goods must be delivered to the buyer's house, or when the buyer must pay the money for the goods. In the case of someone borrowing money, it is often not specified when the money must be returned.

Because default (negligence) has very important consequences, it must be determined beforehand whether the debtor is in default or negligent, and if this is denied by him, it must be proven before a judge. Sometimes it is also not easy to say that someone is negligent or negligent, because often it is also not promised exactly when a party is required to perform the promised performance. In buying and selling goods, for example, it is not stipulated when the goods must be delivered to the buyer's house, or when the buyer must pay the money for the 
goods. In the case of someone borrowing money, it is often not specified when the money must be returned.

The easiest way to determine a person is in default is in an agreement that aims not to do an act. If that person does so, it means he is violating the agreement, and he is in default.

In practice, if a debtor breaks his promise, generally the creditor as the deposit holder does not immediately exercise his right to withdraw the deposit slip which has been signed by the debtor. The steps taken by the parties are:

1) Creditors usually make an approach first, namely by visiting the debtor periodically, at least every month.

2) The results of the meeting with the debtor are stated in the form of a call memo (call visit or call report). The call memo or call report form contains the latest debtor information in terms of business progress, financial conditions and or problems in managing their business. This information becomes very necessary in the context of maintaining debtors, because from this it can be easily identified potential credit problems that may occur in the future. In this way, from an early age the bank will know the potential for this problem, so that in the future it will be easier to handle it. The benefits of kunjuangan carried out by creditors are one of the main duties and responsibilities in addition to finding new debtors for target disbursement. Success in this implementation is closely related to the occurrence of non-performing loans. The relationship that occurs can be a causal relationship, if it is managed to maintain, then the risk of non-performing loans can be reduced, otherwise if it is not successful then the risk of non-performing loans will be even greater.

3) If it turns out that after the visit, problems still arise in fulfilling bank obligations, the pattern of handling has been regulated in the standard operating procedure (SOP) for deposit credit. The SOP for handling this problem is that after being in arrears of interest and/or principal installments within 3 days, the creditor is required to make a warning letter (SP), respectively SP 1 - SP 3 which reminds the debtor of fulfilling the obligations of the debtor for a certain period of time being obliged to pay off the arrears. In the letter, apart from warning the debtors of arrears, it is also emphasized that if they remain in arrears, within 14 days of the arrears, the guarantee deposit will be disbursed to pay off the credit. The disbursement of this guarantee will not only pay off the total arrears but on the entire total the remaining loan, will be paid at once with funds from the guarantee deposit.

4) These warning letters are then filed by the credit administration department to complete the existing legal documentation for each debtor. And if within a period of 14 days the debtor does not make a payment, then on the basis of the SP 1-3 it has become a strong legal basis for the bank to declare that the debtor is in default. So based on this default, the disbursement of the guarantee deposit will be carried out immediately.

5) And the last step taken by the bank is to give written notification to the debtor that the entire loan amount along with the arrears of interest and penalties, has been paid off by disbursement of the deposit.

In the event that the object of the guarantee is a time deposit, if the debtor is declared in default, then based on the previously agreed "Power of Attorney to Disburse" the deposit can be immediately disbursed to pay off the debtor's remaining debt, both principal and interest, fines and other costs. Meanwhile, in the event that the debtor dies, the credit must still be repaid by the heirs. Regarding the guaranteed deposit, the guarantee remains attached, because in the Power of Attorney to Disburse there is a clause stating that the power of attorney cannot be expired and revoked for any reason. ${ }^{31}$ This provision overrides Article 1813 of the Civil Code. 


\section{Conclusion}

Indonesia Tbk, namely at first that the prospective debtor submits a Credit Application Letter (SPK) which is filled in the form provided by the bank by completing all the administration. Then, the bank will conduct a credit analysis in order to assess the ability/feasibility of the prospective debtor in terms of returning his credit, including an analysis of the guarantee.

Efforts made by banks in disbursing credit with deposit guarantees begin with filling in the form of a Certificate of Loan Application (SKPP) by the prospective debtor by the bank and ending with the disbursement of credit by the bank to the debtor, after which the binding is carried out by signing other documents. which must be filled in and signed by the applicant (prospective debtor) in order to disburse credit with time deposit guarantees at PT Bank Danamon Indonesia Tbk Medan Branch, namely; Credit Agreement, Agreement for Submission of Claims (cessie), Submission of Pledge of Securities, Instruction Letter for Loan Disbursement (GPA).

With respect to credit guarantees in the form of deposits for defaulting debtors, the bank still issues warning letters (SP) 1 - up to warning letters (SP) 3 with several attempts, suggestions or alternatives provided by banks to debtors, namely; creditors suggest that repayment of overdue loans be paid off by the debtor with cash funds, not by disbursement of deposits.

If the steps taken have not found a clear spot, then the bank based on the previously agreed "Power of Attorney to Disburse" the deposit can be immediately disbursed to pay off the debtor's remaining debt, both principal and interest, fines and other costs.

\section{References}

Abdulkadir Muhammad, Indonesian Civil Law, Bandung : PT. Citra Aditya Bakti, 2000 Ahmad Anwari, Time Deposit, Balai Aksara, Jakarta, 1998.

Ahmad Anwari Practices in Banking (Term Deposits), PT. Balai Aksara, Jakarta, 1979 Badriyah Harun, Troubled Credit Dispute Resolution, Yogyakarta: Pustaka Yustisia, 2010.

HR Daeng Naja, Credit Law and Bank Guarantee, Bandung: PT. Citra Aditya Bakti, 2005 Hartono Hadisoeprapto, Principles of Engagement Law and Guarantee Law, Liberty, Yogyakarta. 1984.

Hermansyah, “Indonesian National Banking Law”, Ed.Rev. Print 3, Kencana Prenada Media, Jakarta, 2007.

J. Satrio, Law on Guarantee of Property Guarantee Rights, Bandung, PT. Image of Aditya Bakti, 2007.

M. Bahsan, Indonesian Banking Credit Guarantee and Guarantee Law, Jakarta: PT. RajaGrafindo Persada, 2008.

Salim HS, Development of Guarantee Law in Indonesia, Jakarta: PT. RajaGrafindo Persada, 2008.

Muhammad Tjoekam, Credit - The Core Business of Commercial Banks- Engineering Concepts E Cases, Gramedia Pustaka Utama, Jakarta, 2002.

Rachmat Firdaus, Bank Credit Management, Alfabeta, Jakarta, 2009.

Sigit Triandaru and Totok Budisantoso, Banks and Other Financial Institutions, Jakarta, Salemba Empat, 2006.

Simorangkir, O. P, Drs, Fundamentals and Mechanisms of Banking, Indonesian Persada Script, Jakarta, 1986. 
Soerjono Soekanto, Introduction to Legal Research, UI Press, Jakarta, 1982 Subekti, Principles of Civil Law, Jakarta : PT. Intermas, 2003.

Sutan Remy Sjahdeini, "Security Rights and Bankruptcy," in Secured Transactions and Fiduciary Guarantees collected by Arie S. Hutagalung, UI, Jakarta 2006.Suyatmo, Thomas, Drs, et al, Banking Institutions, Gramedia Jakarta, 1989.

Mr. Iswahyudi Arffan D Credit department PT Bank Danamon Indonesia Tbk. Jalan Dipenogoro No. 35 Medan, March 5, 2013.

Mr. Muhammad Zeini, legal officer of PT Bank Danamon Indonesia Tbk, Jalan Dipenogoro, March 10, 2013.

Mr. Khoirudin, Position Relation Manager (RM), PT Bank Danamon Indonesia Tbk Medan Branch, April 5, 2013. 